\title{
Refugees as a Development Resource: The case of the Mozambican refugees in Malawi
}

\author{
Violet Bonga
}

\section{Introduction}

There are three acceptable durable solutions to refugee problems: voluntary repatriation, resettlement in a third country or integration into the host community. In this paper it is argued that integration appears to be the best solution for the Mozambicans in Malawi because, although the war which forced them to flee from their homeland has officially ended, the situation there is still insecure and many refugees will remain in Malawi for some time. Considering that their country of asylum has limited resources, some effort should be made to increase agricultural potential through irrigation and reclaiming marshy areas. For development approaches such as these, we need the support of our donors. Although relief aid is crucial, it is not sufficient in places where refugees stay for extended periods. Lengthy periods of asylum require some provisions for development.

\section{Helpless Refugees?}

Refugees are often considered an economic burden-helpless victims who are unable to alleviate their plight (Harrell-Bond 1986; Mazur 1986). This image implies that the international aid agencies and the host community must provide all inputs for the "care and maintenance" of the newcomers from the day they arrive until the day they repatriate. Their perceived "helplessness" has policy implications because it calls for a top-down approach to all refugee-related issues. This paper demonstrates that, given a chance, these "incapable refugees" can actually enhance the economic development of their country of asylum.

Violet Bonga is an associate professor at Chancellor College, University of Malawi, Zomba, Malawi

\section{Survival Strategies}

The survival of refugees prior to the establishment of formal assistance suggests that they are not as helpless as intervenors would want to imagine. Many have initiated various incomegenerating activities such as selling clay pots, doughnuts, firewood, fish or even part of their rations like flour, cooking oil and pigeon peas in order to get cash for other pressing needs (e.g., maize grinding, salt, transport and hospital fees). In addition to selling relief items, some refugees do "ganyu", i.e., various forms of wage labour like gardening, pounding maize, and even collecting the relations of other refugees left behind in Mozambique. Many rear domestic animals like rabbits, pigeons, chickens, ducks, pigs and goats. Cross-border farming is another activity carried out by refugees, particularly in Ntcheu and Dedza. Carpentry, tinsmithing, construction of other peoples' huts and "kiosks" at the market place are among popular survival strategies. All of these examples show that refugees do not enjoy being dependent and they are often keen to work and earn a living (Mwanza and Seshamani 1988).

\section{Durable Solutions}

Of the three generally accepted durable solutions to refugee influx, voluntary repatriation has only recently become a possibility with the 1992 Rome Peace Accord. (It is true that some refugees have repatriated but it appears that many did not go back to their original homeland which is a clear indication that it is not safe yet for them to go there).

The second alternative is that of resettling the refugees in a third country. Nyerere (1979) was in agreement with this proposition when he said,
I do not believe that dealing with the problem of 3.5 million people and giving them a chance to build their dignity and their lives is an impossible task for 46 nations and their 250 million inhabitants. All refugees are individuals with a right to life in Africa. All need a chance to recreate their lives in Africa, and to regain the dig. nity of being self-reliant and making a contribution to the development of our continent.

This option for the Mozambicans in Malawi may not be attractive because they know that the neighbouring states are also flooded with refugees. Considering the low levels of education and rural background of the majority of the asylum seekers, resettlement would not be an attractive option because they would find it extremely difficult to find employment (Mwanza and Seshamani 1988). Resettlement in the North is not even considered as an option.

For the last option, Harrell-Bond (1986) defined integration as

a situation in which the host and refugee communities are able to coexist, sharing the same resourcesboth economic and social-with no greater mutual conflict than that which exists within the host community.

This solution has some advantages in that it offers refugees a more humane alternative to camp life. They are able to lead a "normal" life because they tend to live with people of the same culture and language. It also gives them an opportunity to take control of their lives and to regain a measure of independence. Regarding this option, any planning for assistance and development must be on a long-term basis.

The major challenge for the ap proach of local integration for refugees is that it is easier to attract aid from donors for short-term relief than for long-term development. It is impera- 
tive that donors take the issue of development to heart. In the case of Malawi, Mozambican refugees have created pressures on public goods and services which have led to the deterioration of the infrastructure and resources of the country (see Dzimbiri's paper). It follows that Malawians who have given up so much for the wellbeing of the refugees should also benefit from any refugee-related development projects introduced. Thus it is important to take a regional approach to "refugee aid and development" which benefits both the refugees and the local population.

There have been successful examples of local integration of refugees in Africa. In Tanzania, refugees from Botswana were made eligible for citizenship, and those from Rwanda, Burundi and pre-independence Mozambique achieved a high degree of self-sufficiency. These refugees shared their externally funded facilities with the local community. In Sudan, rural land settlements, rural wage-earning settlements and suburban settlements were set up-also leading to a measure of self-sufficiency.

In Zambia, a UNHCR-funded settlement for Angolan refugees was quite successful because of fertile soils and adequate rainfall. At Ukwimi settlement in Zambia, Mozambican refugees are said to have harvested up to a thousand bags of maize annually (Mwanza and Seshamani 1988). Kibreab (1987) studied rural refugee settlements in eastern Sudan where each refugee household was given ten feddans (4.2 hectares) of land by the host government. There were some problems associated with the project because participants were not allowed to transfer land and as a result could not practise fallowing and shifting cultivation. Other constraints included shortages of labour, high morbidity rates and the introduction of inappropriate technologies. ${ }^{1}$

In Malawi, some refugees from camps as well as those who have settled among the local population have acquired land. However, in contrast to the examples cited above, refugees tend to have access to land which is not fertile. The lack of fertilizer and sufficient arable land combined with the effects of the drought of 1991-92, made it impossible for refugees to become self-reliant in food production.

\section{Strategies to Increase Local Integration}

Considering the negative impacts to the local population that have resulted from hosting the refugee influx, it is important to find ways of improving the situation for both the Malawians and their refugee counterparts. The crucial question that needs to be answered is, 'how can refugees enhance the development of their country of asylum while at the same time, being regarded as equal members of the local community?' The past experience and knowledge of refugees are often an ignored source of "hidden" capabilities that could be used more fully in the relief program. One area which has realized the potential of the refugees is that of education and health. The children of the refugees are taught by Mozambican teachers-chosen by the refugees themselves. Often the health centres in refugee hosting areas have medical personnel of Mozambican origin.

In the Oxford study, we discovered that the Mozambicans were not a homogeneous group. Among them were engineers, miners, cooks and drivers, although the majority were peasant farmers. This important information was often overlooked by organizations that introduced various "development" projects among the refugee community. For instance, considerable time and funds were wasted in trying to teach the refugees how to grow vegetables, as if they had never done so before! Most of the vegetables sold along the Ntcheu-Dedza stretch of highway between the MozambiqueMalawi border are grown by refugees. The real issue was not the technical know-how of vegetable growing, but the need for inputs such as garden implements, seeds, fertilizer, a water supply and access to fertile land. At Tengani Camp, which is situated very close to the Shire River, it was shocking to see that people were unable to exploit this ample source of water for their gardens. Most of them got the water for watering and brick-moulding from the already congested water points. As a result, people never had sufficient supplies of water and harvests were poor.

In such circumstances, more ambitious attempts to increase regional agricultural production should be considered, for example, the introduction of an irrigation system. The ancient Egyptians, Sumerians, Chinese and Indians flourished because they used the Nile, Euphrates and Tigris, Yangtze and Hwang $\mathrm{Ho}$, and the Indus rivers respectively to such an extent that their lives were transformed (Crowder et al. 1970). There is no reason why the Shire River cannot become the lifeblood of Malawi. Shortages of bricks and a lack of water for domestic needs were major problems in the Southern Region, despite the proximity of the Shire River. There were always long queues at different water points and women often had to line up well before dawn and even in the middle of the night. The introduction of running water to the area would benefit women especially by freeing them to engage in more productive work like income-generating activities. Clean drinking water would also reduce the spread of water-borne diseases common in refugee camps like cholera and dysentery. The cost, lack of reliability, and inconvenience of boreholes would be eliminated. Local Malawian villagers would also benefit from running water and improved health conditions.

Fish farming is another activity that could be developed by redirecting the flow of rivers. A similar project already exists in Ntcheu. In addition, food production would increase since irrigation would allow the extension of the growing season.

Apart from increased agricultural potential from irrigation there is also potential for reclaiming land by draining marshy areas and introducing afforestation programs. The Shire River 
has numerous marshy places that could be developed.

In places where irrigation could not be practised, cross-border farming would be encouraged by assisting refugees with basic inputs like seeds, fertilizers and hoes. After all, people who live very close to the border area already collect firewood, thatch, medicinal herbs and construction materials from Mozambique. Apart from engaging in productive work, they would also be maintaining contact with their homeland and collecting important news about recent developments. It was interesting to note that at Mkutu Village in Dedza, it was the refugees whose granaries were full of maize while the local people had nothing. In some cases, Malawians worked refugee land in Mozambique in return for foodstuffs. Occasionally, Malawians were even given portions of land in Mozambique by their refugee neighbours in gratitude for allowing them to settle in Malawian villages.

\section{NGO-Sponsored Projects}

Refugee women were involved in NGO-sponsored projects where they learned how to sew and knit. Many of them were grateful and contented that they had learned new skills. However, these limited benefits did not continue after the end of the training period. Items produced were often of poor quality and there were limited marketing opportunities. Moreover, inputs like wool and cloth were too expensive for most refugees. A hand-weaving project would have been more appropriate, particularly in the cotton growing areas. Such an undertaking would supply more marketable products and would stimulate the local cotton market.

Many refugees complained of having nothing useful to do. An elderly refugee man at Tengani market said to me,

My daughter, I have come from very far in order to buy fish so that I can sell them. I don't want to be idle. I'm used to doing something with my hands. Since I cannot grow my own food I'd rather engage in trading.
In order for development projects to be effective, they should not be imposed on refugees. Refugees should be given a chance to express their needs and these should be taken into account when designing development projects. If something out of the ordinary has to be introduced, clear explanations must be given to the refugees. Their opinions should be sought on the best way to operate these projects. This period of consultation needs to be done at the earliest stages of project design to increase refugee participation. During our visit to the four districts, we discovered that the people who participated in projects knew little about the finances involved. This information was concealed from them by aid workers because it was felt that the refugees were "children", ignorant of financial responsibility. Yet, when it comes to financial matters, refugees rarely waste a single tambala; they are their own accountants.

The participation of refugees in development projects is important for another reason, instilling a work ethic among children. From the interviews conducted it became clear that refugee parents were very concerned about the future of their children, fearing they would never know the value of hard work. Doing some manual work while in a refugee camp would help prepare refugees for eventual voluntary repatriation. Going home, though exciting, will not mean an easy life. Returnees will have to rebuild their society from scratch.

The promotion of primary and secondary school education for refugees is another important development activity which also provides an opportunity for local integration. However, in Malawi there were many problems in supporting this initiative. Secondary school education is very competitive in Malawi. At the time of the research, a planned secondary school for refugees in Nsanje had not yet opened. Many of the primary school children, especially those in senior classes, did not continue with their education, claiming that it was pointless without the opportunity for further studies. In
Lutaya, southern Sudan, Ugandan refugees together with students from the host population managed to construct a secondary school. The agencies who at first regarded the project as premature and a luxury were "persuaded" to assist by providing them with some materials (Mazur 1986). There is no reason why such cooperation between refugee and host population cannot also be encouraged in Malawi.

The refugees should be made to feel that in their own small way they can work for the improvement of their society. However, it was sad to notice in another self-settled area that this type of cooperation did not exist. When refugees were asked to assist in projects, the local population refused to help once the refugees had started making bricks for the proposed "playground." They claimed that the services rendered by the visitors for local projects was a sign of gratitude for the land they had been offered. Obviously there is an important difference between enlisting the refugee population to work for the local population and supporting spontaneous refugee-host joint projects.

Deforestation in Malawi is a major problem that has been aggravated by the arrival of the Mozambicans. Trees are cut carelessly, and despite efforts of the Malawi Government Forestry Department to control the process, the situation continues to worsen. Many trees are cut after working hours and on Sundays when it is known that forest guards are not on duty. Both the refugees and the Malawians need to be educated on the importance of forests. Those responsible for afforestation programs should employ both groups in tree-planting and management. In places where fruit trees grow easily, refugees should be encouraged to grow their own fruit like papayas, bananas, guavas, hybrid varieties of mango. Considering that many of them have stayed in the country for over six years, by now they should be enjoying the "fruits of their labour" had afforestation projects been initiated at the beginning of the influx. 